\title{
WORK RELATED FACTORS THAT AFFECT BURNOUT AMONG ACCOUNTING
} AND FINANCE ACADEMICIANS

\author{
MELEK EKER \\ Dr. Uludag University, Faculty of Economics and Administrative \\ Sciences Department of Business Administration
}

\author{
ADEM ANBAR \\ Dr.Uludag University, Faculty of Economics and Administrative \\ Sciences Department of Business Administration
}

\begin{abstract}
ÖZET
$B u$ çalışmanın amacı, Türkiye'deki akademisyenlerin tükenmişlik düzeylerini ölçmek ve akademisyenlerin tükenmişlik düzeylerini etkileyen faktörleri araştırmaktır. Veriler, toplam 78 kamu üniversitesinin ve özel üniversitenin İktisadi ve Idari Bilimler Fakültelerinde muhasebe - finansman anabilim dalında görev yapan 160 akademisyenden, sosyo-demografik anket formu, Maslach Tükenmişlik Envanteri ve "i̧̧ ve iş çevresi" ölçeği kullanılarak toplanmıştır. Verilerin analizinde tanımlayıcı istatistik (ortalama ve standart sapma), korelasyon analizi, faktör analizi ve lojistik regresyon analizi kullanılmıştır. Çalışmada, genel tükenmişlik ve tükenmişlik alt boyutlarının skorları, diğer çalışmaların sonuçlarına göre daha düşük bulunmuştur. Akademisyenlerin tükenmişlik düzeylerini etkileme olasılığı bulunan 12 maddeli "iş ve iş çevresi" ölçeğine uygulanan faktör analizi sonucunda, dört temel faktör ortaya çıkmıştır. Bu faktörler; iş çevresi, idari işyükü, akademik işyükü ve ilerleme ve değerlemedir. Bu faktörlerin akademisyenlerin genel tükenmişlik düzeyleri ve tükenmişliğin alt boyutları üzerindeki etkilerini belirlemek amacıyla, lojistik regresyon analizi kullanılmıştır. Lojistik regresyon analizinin sonuçları, tükenmişlik düzeyi üzerinde en fazla etkiye iş çevresi faktörünün sahip olduğunu, bunu, idari işyükü, akademik işyükü ve ilerleme ve değerleme faktörlerinin izlediğini göstermiştir.
\end{abstract}


Anahtar Kelimeler: Tükenmişlik, öğretim elemanları, tükenmişliği etkileyen faktörler, akademik çalışma ve iş çevresi.

\begin{abstract}
:
The purpose of this study was to measure the levels of burnout among academicians and to investigate the factors that affect burnout levels of academicians in Turkey. The data were obtained by using sociodemographic data form, Maslach Burnout Inventory and "work and work environment" scale from 160 academicians that have been working in accounting and finance subdepartment in Faculties of Economics and Administrative Sciences in 78 public and private universities. In the analysis of data, descriptive statistics (mean and standard deviation), correlation analysis, factor analysis and logistic regression analysis were used. In this study, general burnout scores and subscales of burnout scores were found to be lower than other studies. The factor analysis of the 12 item "work and work environment" scale which has possible effects on burnout among academicians revealed four factors: Work environment, administrative workload, academic workload and promotion and evaluation. For determining the possible influence of factors which were revealed by factor analysis upon general burnout levels and burnout subscales, logistic regression analysis was used. Results of the logistic regression analysis indicated that the most significant predictor of burnout was the factor of work environment, followed by the factors of administrative workload, academic workload, and promotion and evaluation.
\end{abstract}

Keywords: Burnout, academicians, factors affecting burnout, academic work and work environment.

\title{
Introduction
}

The feeling of burnout which is experienced heavily in jobs requiring face-to-face relations but which also might be faced in many branches of business, has been described as a psychological syndrome today. This feeling, which is also defined as a reduction of psychological and physical energy that comes out after the process of a chronic stress related with work, is likely to be considered as a higly stressed and felt psychological fact of society of modern performance.

The term burnout was transferred to social sciences from the language of aerospace. While the term burnout is used to describe the consumption of fuel in rockets and nuclear reactors in language of aerospace, in social sciences, burnout is used to define becoming exhausted, especially as a result of overwork or occupational stress (Briscoe, 1984). The concept of burnout was first used by Freudenberger in 1974. Freudenberger (1974) defined burnout as a state of fatigue and emptiness of physical and mental power, a state of 
being worn out. In the most widely used definition which was done by Maslach (1993), burnout is described as "a psychological syndrome of emotional exhaustion, depersonalization, and reduced personal accomplishment that can occur among individuals who work with other people in some capacity." It is a response to the chronic emotional strain of dealing extensively with other individuals, particularly when they are troubled or have problems. It can be considered as one type of job stress. According to Maslach (1993), there are three components of burnout: Emotional exhaustion, depersonalization and reduced personal accomplishment. Emotional exhaustion refers to the depletion of psychic energy or the draining of emotional resources. Depersonalization refers to the development of negative, cynical attitudes toward the recipients of one's services. Reduced personal accomplishment is the tendency to evaluate one's own work with recipients negatively, an evaluation that is often accompanied by feelings of insufficiency. Individuals with high levels of emotional exhaustion report feeling psychologically drained. They have little energy or motivation left from themselves to give to others or to their job. Individuals with high levels of depersonalization report feeling cynical, pessimistic, and apathetic towards one's clients. Low levels of personal accomplishment are associated with feelings of negativity towards oneself, especially in the context of one's relationship to clients.

Burnout is important for business and social life because of its devastative effects. Firstly, burnout has negative impacts on the psychological and physical health of individuals. Burnout is assumed to be a contributing factor in the development of family discord, drug and alcohol abuse, insomnia, and fatigue (Jackson \& Maslach, 1982; Mcdonald \& Siegall, 1998; Evers \& Tomic, 2003; Bailey, 2006). Also, burnout is positively correlated with reports of headaches, sleep disturbances, and other somatic symptoms of stress (Kacmaz, 2005; Taycan et al., 2006; Bauer et al., 2006; Bailey, 2006). Secondly, burnout has an effect on job productivity and performance. In general, burnout decreases job performance, job satisfaction, job commitment and quality of service, and increases absenteeism, low morale, and job turnover (Maslach \& Jackson, 1984; Nowack et al., 1985; Schwab et al., 1986; Rocca \& Kostanski, 2001; Ing-Chung et al., 2003; Marchiori \& Henkin, 2004; Uskun et al., 2005; Toppinen-Tanner et al., 2005; Piko, 2006). In order to suggest prevention strategies, the factors which cause burnout have to be identified and accordingly, differential methods may be recommended. In the last two decades, a lot of studies have been conducted about burnout in both academic world and 
business world for the purpose of explaining the phenomenon and suggesting prevention strategies.

A broad range of occupations can experience burnout. Burnout is a prolonged response to chronic job-related stressors. Thus, various studies have been carried out on members of different occupations such as doctors, nurses, policemen, teachers, librarians, and managers. In these studies, a lot of factors were found to be considerable predictors of burnout. In general, these factors are divided into two groups: Personal (demographics) factors and environmental (organizational and work) factors. Several studies have found that organizational factors and work features were more highly correlated with burnout than personal factors (Pagel \& Wittman, 1986; Lecroy \& Rank, 1987; Schaufeli \& Janczur, 1994; Maslanka, 1996; Zellars et al., 2000; Rocca \& Kostanski, 2001; Kırılmaz et al., 2003). In addition to organizational and work features, some demographic characteristics, such as age, gender and marital status were found to be related to burnout in several studies (Maslach \& Jackson, 1985; Poulin \& Walter, 1993; Sucuoglu \& Kuloglu, 1996; Sarı, 2004; Lau et al., 2005; Siebert, 2006; Taycan et al., 2006; Sunter et al., 2006). Attention to these factors may alleviate symptoms of burnout among employees.

Educators are particularly susceptible to burnout, probably due to the close and persistent contact with students. But, many of the burnout studies related to educators included teachers as participants. Another educator group, academicians also deserve the attention of researchers as an occupational group candidate for burnout symptoms. Several factors contribute to academic burnout due to different work conditions and organizational characteristics. Some of these factors are number of students that one must deal with (Lackritz, 2004: 713), levels of job satisfaction (Seiler/Pearson, 1984: 301), reward systems (ToddMancillas/Johnson, 1987), promotion in occupation (Bilici et al., 1998: 186), level of income/salary (Bilici et al., 1998: 186; Briscoe, 1984: 4), teaching load (Todd-Mancillas/Johnson, 1987), unappreciative students (Todd-Mancillas/Johnson, 1987), budget concerns (Johnson, 1989), administrative style (Johnson, 1989), communication and environmental problems (Johnson, 1989), job security (University of Plymouth, 2003: 6; Tytherleigh, 2005: 41), time invested in various activities (Lackritz, 2004: 713) and personal characteristics such as age, gender, and marital status (Lackritz, 2004: 713; Faculty Recruitment \& Retention Committee, 1999: 11; Jaschik, 2005; Johnson, 1989; Bilici et al., 1998: 181; Özdemir et al., 1999: 98; Barut/Kalkan, 2002: 66). 
In our study, organizational and work related factors that affect burnout levels of academicians were examined, so that results of the related litareture were presented here in detail. In these studies, different findings have been found. A study which was done by Johnson (1989) to identify factors contributing to burnout experienced by full time faculty members and sfaff showed that full-time faculty burnout was a significant problem; gender, ethnicity and length of service were not significantly related to burnout; and major contributors to burnout were treatment of faculty, budget concerns, administrative style, the cluster system, communication problems and environmental problems. Lackritz (2004) examined burnout among 265 university faculty members and found that burnout showed significant correlations with numbers of students taught, time invested in various activities and numerical student evaluations. Talbot (2000) investigated the relationship between burnout among community college nursing faculty members and their use of humor to mediate academic stress related to burnout, and found that differences in burnout between high versus low humor usage respondents showed a higher sense of personal accomplishment with high humor usage and workload was related to emotional exhaustion and depersonalization with low humor usage. Neidle (1984) concluded that burnout often occurs at various intervals throughout one's academic career. McDonald and Siegall (1998) explored the effects of job burnout and positive expectations regarding alcohol use among university professors. Results of this study showed that faculty members who experienced greater degrees of job burnout and had more positive expectations regarding the use of alcohol reported a significantly higher level of binge drinking. Differences in factors contributing to the relationship between burnout and drinking were found between men and women. Diminished personal accomplishment was found significantly related to drinking for women and depersonalization was found significantly related to drinking for men. Doyle and Hind (1998) examined whether differences in work-related stress and burnout existed among male and female academics working in psychology departments. They found that females had greater work stress but lower levels of burnout. Siegall and McDonald (2004) investigated the role of person-organization value congruence on the experience of burnout among academicians. They found that burnout was associated with less time spent on teaching, service/administrative tasks and professional development activities and person-organization value congruence was strongly associated with burnout. Singh et al. (1998) investigated the effects of intrinsic motivation to do research and perceived lack of rewards contingent on doing research on burnout 
among academicians and found that these two variables were related to burnout. In other words, the effects of perceived lack of rewards contingent on doing research and intrinsic motivation to do research contributed to burnout levels of academicians. Chalmers (1998) investigated workload and stress in New Zealand universities and found that the main sources of work related stress for many university staff were linked to their work and workload, rather than the contents of their jobs, most academicians worked in the evening or took work home on one evening or more a week, and university staff were concerned about funding, career prospects, the ability to exercise academic freedom and to take research leave and working life in general. Jacobs and Winslow (2004) stated that academicians have more autonomy regarding the substance of their work and more flexibility in their daily schedules but they work long hours for less pay than many other professionals. These researchers indicated that the average workweek for full-time academicians exceeds fifty hours.

In Turkey, there is not enough research about burnout among Turkish academicians and most of these studies are related to the relationship between burnout levels and demographic factors. In these studies, Barut and Kalkan (2002) investigated the relationship between burnout and demographic characteristics among academicians in Ondokuz Mayıs University; Özdemir et al. (1999) compared the levels of burnout among academicians in two faculties in Cumhuriyet University; Bilici et al. (1998) investigated the association between the level of burnout and demographic factors and depression in five faculties in Karadeniz Technical University. The aim of this study is to explore the levels of burnout among academicians and to investigate the factors that affect burnout levels of academicians.

\section{Methodology}

\section{Population of the study and sample}

The population of the study comprised academicians that have been working in accounting and finance sub-departments in faculties of Economic and Administrative Sciences in 78 public and private universities in Turkey. The questionnaires were sent through electronic mail to 400 academic staff which constitutes the universe of the study. The survey was conducted between May 1, 2006 and July 30, 2006. A total of 160 completed questionnaires were received back, giving a response rate of $40 \%$.

Data instruments 
Data were collected using three different questionnaires. The first questionnaire was sociodemographic data form which was designed to gather information regarding gender, age, marital status and number of children, level of education, academic title, institution, years in occupation and years in institution. This questionnaire consisted of nine questions.

The second questionnaire was the Maslach Burnout Inventory (MBI) which developed by Maslach and Jackson (1981) and for measuring burnout. It has been translated and adapted into Turkish by Ergin (1992). The inventory consists of 22 items forming three subscales: Emotional exhaustion, personal accomplishment and depersonalization. The emotional exhaustion subscale consists of nine items which describe feelings of being emotionally over extended and exhausted by one's work. The five items on the depersonalization subscale describe unfeeling and impersonal responses to co-workers or recipients of services. The personal accomplishment subscale consists of eight items, describing feelings of competence and success about one's achievements. These items' coding was reversed in this study therefore the analyses were done after adjusting the reverse items. The items in the scale are scored on a five-point scale ranging from "never" (0) to "always" (4). High scores on emotional exhaustion and depersonalization, and low scores on personal accomplishment are indicative of burnout. For determining the reliability of the Maslach Burnout Inventory used in this study, Cronbach's alpha was used. Cronbach's alpha coefficient was 0,88 for general burnout, 0,86 for emotional exhaustion, 0,72 for depersonalization, and 0,58 for personal accomplishment.

The third questionnaire was "work and work environment" scale which was developed by Houston et al. (2004) for investigating the factors that affect burnout levels of academicians. This scale was translated into Turkish and performed a validity and reliability analysis of the Turkish version of the scale by ourselves. The "work and work environment" scale consists of 13 items with five alternative responses i.e., strongly agree, agree, undecided, disagree and strongly disagree which are scored from 1 to 5 .

Analysis of data

The data were analyzed by using SPSS 13 (The Statistical Package for Social Sciences). The descriptive data analysis was conducted by calculating frequencies, mean scores and standard deviations for describing background characteristics of the respondents and determining burnout levels. Pearson correlations were calculated to 
examine the associations among the burnout subscales. Exploratory factor analysis was used to uncover the latent structure (dimensions) of the items in the "work and work environment" scale. Logistic regression analysis was used to assess the effect of the work and work environment factors on general burnout level and burnout subscales.

\section{Findings}

The findings of the study were examined in two sections. In the first section, the demographic characteristics of the respondents, and in the second section, the results of the analyses were presented.

Demographic characteristics of the respondents

Demographic characteristics of the sample are shown in Table 1. The table shows the distribution of respondents by gender, age, marital status, number of children, level of education, institution (public or private university), academic title, years in institution and years in occupation (tenure).

As seen in Table 1,66\% of the respondents were female and $34 \%$ of the respondents were male. According to the age of academicians, $28,9 \%$ of the respondents were between $21-30$ years, $44,7 \%$ of the respondents were between $31-40$ years, $19,5 \%$ of the respondents were between $41-50$ years. Only 1,3\% of the respondents were 61 or above years of age. Most of the participants were married (71\%). While $44 \%$ of the participants had no children, $56 \%$ of them had one or more children. According to the level of education, $70 \%$ of the academicians had Ph.D. degree. According to the academic title, 35,2\% of the respondents were research assistant, $12,6 \%$ of the respondents were lecturer, $30,2 \%$ of the respondents were assistant professor, $12,6 \%$ of the respondents were associate professor and $9,4 \%$ of the respondents were professor. While $88,7 \%$ of the participants had worked in a public university, $11,3 \%$ of the participants had worked in a private university. According to the years in occupation or tenure, $22 \%$ of the participants had been in high education between 1-5 years, $25,2 \%$ of the participants had been in higher education between $6-10$ years, $28,3 \%$ of the participants had been in higher education between $11-15$ years, $\% 8,8$ of the participants had been in higher education between 16- 20 years and $11,9 \%$ of the participants had been in higher education for more than 20 years. According to the years in institution, percent rates were equal for $1-5$ years, $6-10$ years and $11-15$ years. It 
was seen that $15,6 \%$ of the participants had been at the institution for more than 15 years.

\section{Results}

\section{Burnout scores of academicians}

The means and standard deviations of the general burnout and three burnout subscale scores are shown in Table 2. As seen in Table 2, four different scores were calculated; general burnout score, emotional exhaustion score, depersonalization score and personal accomplishment score. Possible minimum - maximum-scores were 0$88,0-36,0-20$ and $0-32$ for general burnout, emotional exhaustion, depersonalization and personal accomplishment, respectively. The higher mean scores of the emotional exhaustion and depersonalization subscales and lower mean scores on personal accomplishment subscale correspond to greater degrees of burnout. The general burnout scores changed between 7-61, mean score of the general burnout was 24,7 and standard deviation of the general burnout score was 10.25 . While the mean score on the emotional exhaustion subscale was $10,2(S D=6,10)$, the mean score on the depersonalization subscale was $2,9(S D=2,64)$. On the personal accomplishment subscale, the mean score was $11,6(S D=3,45)$. The average scores seem to imply that burnout levels of academicians were not higher, however, since a norm table of the burnout level of academicians that would make comparisons possible does not exist, this conclusion has to be approached with caution.

Table 2. Means and standard deviations of burnout scores

\begin{tabular}{|l|c|c|c|r|r|r|}
\hline Subscales & $\mathbf{N}$ & $\begin{array}{c}\text { Item } \\
\text { Number }\end{array}$ & Mean & $\begin{array}{c}\text { Std. } \\
\text { Deviation }\end{array}$ & $\begin{array}{c}\text { Minimum } \\
\text { Score }\end{array}$ & $\begin{array}{c}\text { Maximum } \\
\text { Score }\end{array}$ \\
\hline $\begin{array}{l}\text { Emotional } \\
\text { Exhaustion }\end{array}$ & 160 & 9 & 10,2000 & 6,10269 &, 00 & 30,00 \\
\hline Depersonalization & 160 & 5 & 2,9250 & 2,64349 &, 00 & 13,00 \\
\hline $\begin{array}{l}\text { Personal } \\
\text { Accomplishment }\end{array}$ & 160 & 8 & 11,6000 & 3,44991 & 5,00 & 24,00 \\
\hline General Burnout & 160 & 22 & 24,7250 & 10,25704 & 7,00 & 61,00 \\
\hline
\end{tabular}

To examine the relationship between the general burnout and burnout subscales, Pearson correlation analysis was used. The results of this anaysis are shown in Table 3. There were significant positive relationships among general burnout and burnout subscales. General 
burnout was strongly correlated with the level of emotional exhaustion subscale $(r=0,94)$. Also, there were significant intercorrelations among burnout subscales. The emotional exhaustion had positive and significant correlations with depersonalization and personal accomplishment. The relationship between personal accomplishment and depersonalization was significant, but lower.

Table 3. Correlation coefficients

\begin{tabular}{|l|r|r|r|r|}
\hline Subscales & \multicolumn{1}{|c|}{ EE } & \multicolumn{1}{c|}{ D } & \multicolumn{1}{c|}{ PA } & \multicolumn{1}{c|}{ GB } \\
\hline Emotional Exhaustion (EE) & 1 &, $661\left(^{* *}\right)$ &, $529\left(^{* *}\right)$ &, $943\left(^{* *}\right)$ \\
\hline Depersonalization (D) &, $661\left(^{* *}\right)$ & 1 &, $300\left(^{* *}\right)$ &, $752\left(^{* *}\right)$ \\
\hline Personal Accomplishment (PA) &, $529\left(^{* *}\right)$ &, $30\left(^{* *}\right)$ & 1 &, $728\left(^{* *}\right)$ \\
\hline General Burnout (GB) &, $943\left(^{* *}\right)$ &, $\left.7522^{(* *}\right)$ &, $728\left(^{* *}\right)$ & 1 \\
\hline
\end{tabular}

** $p=0.01$ significance level (Pearson Correlation)

\section{Factor analysis}

Exploratory factor analysis was used to assess the work and work environment factors that were supposed to affect burnout among academicians. Firstly, KMO (Kaiser-Meyer-Olkin) sampling adequacy measure was calculated for determining the convenience of data for factor analysis. KMO varies from 0 to 1 . This measure shows that sampling is convenient for factor analysis when it is close to 1 and it shows that sampling is not convenient for factor analysis when it is under 0,50 . KMO sampling adequacy measure was 0,765 , therefore, sampling was convenient for factor analysis. Also, significance level of Bartlett test was calculated as 0,00 . Consequently, both of the tests showed that factor analysis could be applied to the data.

In the factor analysis, principal components analysis and varimax rotation technique were used. The obtained factor analysis results were examined, because of the the factor related to research fund having only one item, the analysis has been done again excluding that variable. The results of this analysis revealed four factors with eigenvalues of 1,0 or higher. These factors explained $65 \%$ of the total variance. Factor 1 explained the highest proportion of the total variance $(22 \%)$ and consisted of items which were labeled "work environment". Factor 2 explained $16,15 \%$ of the total variance and consisted of items which were related to "administrative workload". Factor 3 explained $13,8 \%$ of the total variance and factor 4 explained $13 \%$ of the total variance and they consisted of items which were related to "academic 
(occupational) workload" and "promotion and evaluation", respectively. Table 4 shows factor distribution of items.

Table 4. Factor analysis results of work and work environment scale

\begin{tabular}{|l|c|c|c|c|}
\hline Work and Work Environment Factors & $\begin{array}{c}\text { Factor } \\
\mathbf{1}\end{array}$ & $\begin{array}{c}\text { Factor } \\
\mathbf{2}\end{array}$ & $\begin{array}{c}\text { Factor } \\
\mathbf{3}\end{array}$ & $\begin{array}{c}\text { Factor } \\
\mathbf{4}\end{array}$ \\
\hline Work Environment & & & & \\
\hline $\begin{array}{l}\text { I am willing to put in a great deal of effort in } \\
\text { order to help this university be successful. }\end{array}$ &, 474 & & & \\
\hline I feel acknowledged for a job well done. &, 884 & & & \\
\hline $\begin{array}{l}\text { I am supported when change and new } \\
\text { initiatives are being introduced. }\end{array}$ &, 850 & & & \\
\hline $\begin{array}{l}\text { Staff morale is high within my department, } \\
\text { institute, school, or unit. }\end{array}$ &, 763 & & &, 863 \\
\hline $\begin{array}{l}\text { Administrative Workload } \\
\text { The amount of administration I am expected to } \\
\text { do is reasonable. }\end{array}$ & &, 587 & & \\
\hline $\begin{array}{l}\text { The number of students I am expected to } \\
\text { teach and/or supervise is reasonable. }\end{array}$ & &, 812 & & \\
\hline I have time to do good quality research. & &, 703 & & \\
\hline $\begin{array}{l}\text { Academic Workload } \\
\text { My workload has increased over the past 12 } \\
\text { months. }\end{array}$ & & & & \\
\hline $\begin{array}{l}\text { I often need to work after hours to meet my } \\
\text { work requirements. }\end{array}$ & &, 718 & \\
\hline $\begin{array}{l}\text { Promotion and Evaluation } \\
\text { achievements are considered equally by } \\
\text { promotion committees. }\end{array}$ & & & & \\
\hline I know what is expected of me in my role. & & & & \\
\hline $\begin{array}{l}\text { I believe the promotion procedures recognize } \\
\text { believe that work that staff do. }\end{array}$ & & & & \\
\hline
\end{tabular}

For internal reliability of the factors, Cronbach's alpha coefficient was calculated and reliability of the factors were $0,772,0,661,0,648$ and 0,549 for work environment, administrative workload, academic 
workload and promotion and evaluation, respectively. Also, total reliability of the scale was 0,781 Therefore, Work and Work Environment scale appeared to be a reliable instrument.

\section{Logistic regression analysis}

In this section, the effects of variables which were revealed by factor analysis (work environment, administrative workload, academic workload and promotion and evaluation) upon burnout levels of academicians were investigated by using a logistic regression analysis. For this purpose, logistic regression analysis was used which is one of the multi variable statistical techniques and aimed to appraise the relationships between the dependent variable and metric independent variables. As it's known, in a logistic regression analysis the effects of independent variables on dependent variables are determined by using probability of the levels of dependent variables. Logistic regression was preferred instead of other similar methods such as regression analysis and discriminant analysis because of its less stringent assumptions. Logistic regression does not assume linearity of relationship between the independent variables and the dependent, does not require normally distributed variables, and does not assume homoscedasticity. For selecting variables in the logistic regression the stepwise forward selection method was used. In the logistic regression analysis, for determining the impact of independent variables on dependent variables, the academicians who had low scores of general burnout, emotional exhaustion, depersonalization and personal accomplishment was coded with the reference category $=0$ and the academicians who had high scores of general burnout, emotional exhaustion, depersonalization and personal accomplishment was coded with the reference category $=1$.

Predictor variables of general burnout. In the logistic regression model which was constituted for determining the effect of predictor variables (work environment, administrative workload, academic workload, promotion and evaluation, and research fund) on general burnout levels of academicians, Hosmer-Lemeshow statistic was 7,637, -2 log likelihood statistic (LL) was 58,024 and significant level (p) was $0,470(p>, 05)$ with 8 degrees of freedom. The results of goodness-of-fit test which are shown in Table 6 indicated that the logistic regression model was not a good fit. The Cox and Snell $R^{2}$ was found to be $9,8 \%$ in the first step and this statistic indicated that there was an approximately 
$10 \%$ relationship between general burnout and predictor variable of work environment. Also, Nagelkerke $\mathrm{R}^{2}$ indicated that there was a $25,3 \%$ relationship between general burnout and work environment predictor variable. In other words it showed that $25 \%$ of the variation in the dependent variable was explained by work environment predictor in the model.

Table 5. Goodness-of-fit test of model for general burnout

\begin{tabular}{|c|c|c|c|c|c|c|}
\hline Step & $\begin{array}{c}\mathbf{- 2} \text { Log } \\
\text { likelihood }\end{array}$ & $\begin{array}{c}\text { Cox \& Snell } \\
\mathbf{R}^{2}\end{array}$ & $\begin{array}{c}\text { Nagelkerke } \\
\mathbf{R}^{2}\end{array}$ & $\begin{array}{c}\text { Chi- } \\
\text { square }\end{array}$ & Df & Sig. \\
\hline 1 & $58,024(a)$ &, 098 &, 253 & 7,637 & 8 &, 470 \\
\hline
\end{tabular}

a: Estimation terminated at iteration number 7 because parameter estimates changed by less than ,001.

Table 6 shows the results of the regression model which was constituted for determining the predictors of general burnout. In Table 6, "B" column shows the coefficients (called Beta Coefficients) associated with each predictor, "sig." column shows the significant levels and "Exp(B)" column shows the odds ratios. The odds ratio is defined as the probability of the outcome event occurring divided by the probability of the event not occurring and the odds ratio for a predictor tells the relative amount by which the odds of the outcome increase (odds ratio greater than 1,00) or decrease (odds ratio less than 1,00) when the value of the predictor value is increased by 1.0 units. In the model, the "B" coefficent was 1,374 for work environment factor, $p$ value was 0,001 and the model was statistically significant $(p<, 05)$. The odds ratio was 3,950 and it indicated that one unit increase in work environment increases 3,950 times the odds of increasing general burnout.

Table 6. Results of logistic regression for general burnout

\begin{tabular}{|l|l|r|r|r|r|r|r|r|r|}
\hline & & & & & & & & \multicolumn{2}{|c|}{$\begin{array}{c}95,0 \% \text { C.I.for } \\
\text { EXP(B) }\end{array}$} \\
\cline { 8 - 12 } & & B & S.E. & Wald & Df & Sig. & Exp(B) & Lower & Upper \\
\hline $\begin{array}{l}\text { Step } \\
\text { 1(a) }\end{array}$ & $\begin{array}{l}\text { Work } \\
\text { Environment }\end{array}$ & 1,374 &, 397 & 11,988 & 1 &, 001 & 3,950 & 1,815 & 8,597 \\
\cline { 2 - 7 } & Constant & $-5,421$ &, 546 & 39,263 & 1 &, 000 &, 033 & & \\
\hline
\end{tabular}

a: Variable(s) entered on step 1: Work Environment.

The success of the logistic regression can be assessed by looking at the classification table. Table 7 shows correct and incorrect estimates. The columns are the two predicted values of the dependent, 
while the rows are the two observed (actual) values of the dependent. According to this table, when decreasing of general burnout level was $100 \%$, increasing of general burnout level was $0 \%$. The overall correct classification percentage of the model was $93,2 \%$.

Table 7. Classification table of logistic regression for general burnout

\begin{tabular}{|c|c|c|c|c|}
\hline & \multicolumn{2}{|c|}{ Predicted } & \multirow{3}{*}{$\begin{array}{l}\text { Percentage } \\
\text { Correct }\end{array}$} \\
\hline & & \multicolumn{2}{|c|}{ GB } & \\
\hline & & 0 & 1 & \\
\hline \multirow{2}{*}{$\begin{array}{c}\text { Observed } \\
\text { GB }\end{array}$} & 0 & 140 & 0 & 100,0 \\
\hline & 1 & 10 & 0 & , 0 \\
\hline \multicolumn{2}{|l|}{$\begin{array}{l}\text { Overall } \\
\text { Percentage }\end{array}$} & & & 93,3 \\
\hline
\end{tabular}

The cut value is, 500

Predictor variables of emotional exhaustion. In the logistic regression model which was constituted for determining the effect of predictors on emotional exhaustion levels of academicians, HosmerLemeshow statistic was 6,399 and marginal significant level was 0,603 $(p>, 05)$ with 8 degrees of freedom. The results of goodness-of-fit test which are shown in Table 9 indicated that the logistic regression model was not a good fit. When the Cox and Snell $R^{2}$ indicated that $21,8 \%$ of the variation in emotional exhaustion level was explained by work environment, administrative workload and academic workload, Nagelkerke $\mathrm{R}^{2}$ indicated that $42,9 \%$ of the variation in emotional exhaustion level was explained by these three predictor variables in the model.

Table 8. Goodness-of-fit test of model for emotional exhaustion

\begin{tabular}{|l|c|r|r|r|r|r|}
\hline Step & $\begin{array}{c}-\mathbf{2} \text { Log } \\
\text { likelihood }\end{array}$ & $\begin{array}{c}\text { Cox \& Snell } \\
\mathbf{R}^{\mathbf{2}}\end{array}$ & $\begin{array}{c}\text { Nagelkerke } \\
\mathbf{R}^{\mathbf{2}}\end{array}$ & $\begin{array}{c}\text { Chi- } \\
\text { square }\end{array}$ & Df & Sig. \\
\hline $\mathbf{1}$ & $83,404(\mathrm{a})$ &, 140 &, 276 & 9,910 & 8 &, 271 \\
\hline $\mathbf{2}$ & $78,948(\mathrm{a})$ &, 165 &, 326 & 14,608 & 8 &, 067 \\
\hline $\mathbf{3}$ & $73,696(\mathrm{~b})$ &, 194 &, 383 & 5,373 & 8 &, 717 \\
\hline $\mathbf{4}$ & $69,207(\mathrm{~b})$ &, 218 &, 429 & 6,399 & 8 &, 603 \\
\hline
\end{tabular}

a: Estimation terminated at iteration number 6 because parameter estimates changed by less than, 001 .

b: Estimation terminated at iteration number 7 because parameter estimates changed by less than, 001 . 
Table 9 shows the results of the regression model which was constituted for determining the predictors of emotional exhaustion. The table's left column shows that stepwise model-building process included four steps. In the first step, a constant as well as work environment predictor variable was entered into the model, at the second step, administrative workload predictor variable was added to the model, at the third step, academic workload predictor variable was added to the model and at the four step, promotion and evaluation predictor variable was added to the model. The beta coefficient $(B)$ of work environment was 1,783 and $p$ value was 0,00 and statistically significant at 0,05 level $(p<, 05)$. The odds ratio of work environment predictor was 5,945 and this statistic indicated that one unit increase in work environment increases 5,945 times the odds of increasing emotional exhaustion. The beta coefficient for administrative workload was 0,960 and $p$ value was 0,010 and significant at 0,05 level. The odds ratio of administrative workload was 2,611 and indicated that one unit increase in this independent variable increases 2,611 times the odds of increasing emotional exhaustion. The beta coefficient for academic workload was 1,313 and $p$ value was 0,013 and significant at 0,05 level. The odds ratio of academic workload was 3,715 and indicated that one unit increase in this independent variable increases 3,715 times the odds of emotional exhaustion. The beta coefficient for promotion and evaluation was 0,636 and $p$ value was $0,039(p<, 05)$. The odds ratio of promotion and evaluation was 1,889 and indicated that one unit increase in promotion and evaluation predictor variable increases 1,889 times the odds of increasing emotional exhaustion when other variables are controlled.

Table 9. Results of logistic regression for emotional exhaustion

\begin{tabular}{|c|c|c|c|c|c|c|c|c|c|}
\hline & & \multirow[b]{2}{*}{ B } & \multirow[b]{2}{*}{ S.E. } & \multirow[b]{2}{*}{ Wald } & \multirow[b]{2}{*}{ Df } & \multirow[b]{2}{*}{ Sig. } & \multirow[b]{2}{*}{$\operatorname{Exp}(B)$} & \multicolumn{2}{|c|}{$\begin{array}{c}\text { 95,0\% C.I.for } \\
\text { EXP(B) }\end{array}$} \\
\hline & & & & & & & & Lower & Upper \\
\hline \multirow[t]{2}{*}{$\begin{array}{l}\text { Step } \\
1(a)\end{array}$} & $\begin{array}{l}\text { Work } \\
\text { Environment }\end{array}$ & 1,333 & ,320 & 17,292 & 1 & ,000 & 3,791 & 2,023 & 7,104 \\
\hline & Constant & 2,685 & 394 & 46,426 & 1 & ,000 & ,068 & & \\
\hline \multirow[t]{3}{*}{$\begin{array}{l}\text { Step } \\
\text { 2(b) }\end{array}$} & $\begin{array}{l}\text { Work } \\
\text { Environment }\end{array}$ & 1,335 & ,328 & 16,518 & 1 & ,000 & 3,798 & 1,996 & 7,229 \\
\hline & $\begin{array}{l}\text { Administrative } \\
\text { Workload }\end{array}$ & 609 & 299 & 4,145 & 1 & ,042 & 1,838 & 1,023 & 3,302 \\
\hline & Constant & $2,790^{-}$ & ,412 & 45,769 & 1 & ,000 & ,061 & & \\
\hline
\end{tabular}




\begin{tabular}{|c|c|c|c|c|c|c|c|c|c|}
\hline \multirow[t]{4}{*}{$\begin{array}{l}\text { Step } \\
\text { 3(c) }\end{array}$} & $\begin{array}{l}\text { Work } \\
\text { Environment }\end{array}$ & 1,543 & ,367 & 17,663 & 1 & ,000 & 4,678 & 2,278 & 9,606 \\
\hline & $\begin{array}{l}\text { Administrative } \\
\text { Workload }\end{array}$ & ,860 & ,342 & 6,332 & 1 & ,012 & 2,364 & 1,210 & 4,621 \\
\hline & $\begin{array}{l}\text { Academic } \\
\text { Workload }\end{array}$ & ,937 & ,444 & 4,451 & 1 & ,035 & 2,551 & 1,069 & 6,091 \\
\hline & Constant & 3,185 & ,524 & 36,942 & 1 & ,000 &, 041 & & \\
\hline \multirow[t]{5}{*}{$\begin{array}{l}\text { Step } \\
\text { 4(d) }\end{array}$} & $\begin{array}{l}\text { Work } \\
\text { Environment }\end{array}$ & 1,783 & ,428 & 17,379 & 1 & ,000 & 5,945 & 2,572 & 13,745 \\
\hline & $\begin{array}{l}\text { Administrative } \\
\text { Workload }\end{array}$ & ,960 & ,372 & 6,662 & 1 & ,010 & 2,611 & 1,260 & 5,411 \\
\hline & $\begin{array}{l}\text { Academic } \\
\text { Workload }\end{array}$ & 1,313 & ,527 & 6,212 & 1 & ,013 & 3,715 & 1,324 & 10,429 \\
\hline & $\begin{array}{l}\text { Promotion } \\
\text { and } \\
\text { Evaluation }\end{array}$ & ,636 & , 308 & 4,255 & 1 & ,039 & 1,889 & 1,032 & 3,456 \\
\hline & Constant & 3,555 & ,633 & 31,520 & 1 & ,000 & ,029 & & \\
\hline
\end{tabular}

a: Variable(s) entered on step 1: Work Environment.

b: Variable(s) entered on step 2: Administrative Workload.

c: Variable(s) entered on step 3: Academic Workload.

$\mathrm{d}$ : Variable(s) entered on step 4: Promotion and Evaluation

The classification table of the model is shown in Table 10. According to this table, the correct classification percentage of low level of emotional exhaustion was $97,7 \%$ and the correct classification percentage of high level of emotional exhaustion was $47,1 \%$. The overall correct classification percentage of the model was $92,0 \%$.

Table 10. Classification table of logistic regression for emotional exhaustion

\begin{tabular}{|l|l|c|c|l|}
\hline \multirow{2}{*}{\multicolumn{2}{|c|}{}} & \multicolumn{2}{|l|}{ Predicted } & \multirow{2}{*}{$\begin{array}{l}\text { Percentage } \\
\text { Correct }\end{array}$} \\
\cline { 3 - 4 } \multicolumn{2}{c|}{} & \multicolumn{2}{|c|}{ EE } & \\
\cline { 2 - 4 } & $\mathbf{0}$ & $\mathbf{1}$ & 97,7 \\
\hline \multirow{2}{*}{$\begin{array}{c}\text { Observed } \\
\text { EE }\end{array}$} & 0 & 130 & 3 & 47,1 \\
\cline { 2 - 4 } & 1 & 9 & 8 & 92,0 \\
\hline \multicolumn{2}{|l|}{ Overall Percentage } & & & \\
\hline
\end{tabular}

The cut value is, 500

Predictor variables of depersonalization. Table 11 shows the goodness-of-fit test of the logistic regression model which was constituted for determining the effect of predictors on depersonalization levels of academicians. As seen in Table 11, Hosmer-Lemeshow statistic was 0,000 and marginal significant level was $1,00(p>, 05)$ with 8 
degrees of freedom. These results indicated that the logistic regression model was not a good fit. Cox and Snell $\mathrm{R}^{2}$ indicated that $10,1 \%$ of the variation in depersonalization level was explained by administrative workload and Nagelkerke $\mathrm{R}^{2}$ indicated that $76,6 \%$ of the variation in depersonalization level was explained by administrative workload predictor variable.

Tablo 11. Goodness-of-fit test of model for depersonalization

\begin{tabular}{|c|c|c|c|c|c|c|}
\hline Step & $\begin{array}{c}\text {-2 Log } \\
\text { likelihood }\end{array}$ & $\begin{array}{c}\text { Cox \& } \\
\text { Snell R } \\
\text { Square }\end{array}$ & $\begin{array}{c}\text { Nagelkerke } \\
\text { R Square }\end{array}$ & $\begin{array}{c}\text { Chi- } \\
\text { square }\end{array}$ & Df & Sig. \\
\hline 1 & $5,253(a)$ &, 101 &, 766 &, 000 & 8 & 1,000 \\
\hline
\end{tabular}

a: Estimation terminated at iteration number 14 because parameter estimates changed by less than ,001

Table 12 shows the results of the regression model which was constructed for determining the predictors of depersonalization. The beta coefficient (B) of administrative workload was 28,395. Pvalue $=0,229$ was found and it was not statistically significant at 0,05 level $(p>, 05)$.

Table 12. Results of logistic regression for depersonalization

\begin{tabular}{|c|c|c|c|c|c|c|c|c|c|}
\hline & & \multirow{2}{*}{ B } & \multirow[b]{2}{*}{ S.E. } & \multirow{2}{*}{ Wald } & \multirow[b]{2}{*}{ Df } & \multirow[b]{2}{*}{ Sig. } & \multirow[b]{2}{*}{$\operatorname{Exp}(B)$} & \multicolumn{2}{|c|}{$\begin{array}{c}\text { 95,0\% C.I.for } \\
\text { EXP(B) }\end{array}$} \\
\hline & & & & & & & & Lower & Upper \\
\hline \multirow[t]{2}{*}{$\begin{array}{l}\text { Step } \\
\text { 1(a) }\end{array}$} & $\begin{array}{l}\text { Administrative } \\
\text { Workload }\end{array}$ & 28,395 & 23,610 & 1,446 & 1 & ,229 & $2 E+012$ & ,000 & $3 E+032$ \\
\hline & Constant & $51,516^{-}$ & 41,564 & 1,536 & 1 & ,215 & ,000 & & \\
\hline
\end{tabular}

a: Variable(s) entered on step 1: Administrative Workload.

As seen in Table 13, the correct classification percentage of low level of depersonalization was $100 \%$ and the correct classification percentage of high level of depersonalizaiton was $50 \%$. The overall correct classification percentage of the regression model for depersonalizaiton was $99,3 \%$.

Table 13. Classification table of logistic regression for depersonalization

\begin{tabular}{|c|c|c|c|l|}
\hline \multicolumn{2}{|c|}{} & \multicolumn{2}{|l|}{ Predicted } & \multirow{2}{*}{$\begin{array}{l}\text { Percentage } \\
\text { Correct }\end{array}$} \\
\cline { 3 - 4 } & \multicolumn{2}{|c|}{ D } & \\
\cline { 3 - 4 } & $\mathbf{0}$ & $\mathbf{1}$ & 100 \\
\hline Observed & 0 & 148 & 0 & \\
\hline
\end{tabular}




\begin{tabular}{|c|l|l|l|l|}
\hline D & 1 & 1 & 1 & 50,0 \\
\hline \multicolumn{2}{|c|}{ Overall Percentage } & & & 99,3 \\
\hline
\end{tabular}

The cut value is ,500

Predictor variables of personal accomplishment. In the logistic regression model which was constituted for determining the effect of predictor variables on personal accomplishment levels of academicians, Hosmer-Lemeshow statistic was 14,501 and marginal significant level was $0,070(p>, 05)$ with 8 degrees of freedom. The results of goodnessof-fit test which are shown in Table 15 indicated that the logistic regression model was a good fit. The Cox and Snell $R^{2}$ was found to be $20,2 \%$ in the second step and indicated that approximately $20 \%$ of the variation in personal accomplishment level was explained by work environment predictor and promotion and evaluation predictor. According to the Nagelkerke $\mathrm{R}^{2}, 37,9 \%$ of the variation in personal accomplishment was explained by these two predictors.

Table 14. Goodness-of-fit test of model for personal accomplishment

\begin{tabular}{|l|c|r|r|r|r|r|}
\hline Step & $\begin{array}{c}-\mathbf{- 2} \text { Log } \\
\text { likelihood }\end{array}$ & $\begin{array}{c}\text { Cox \& Snell R } \\
\text { Square }\end{array}$ & $\begin{array}{c}\text { Nagelkerke R } \\
\text { Square }\end{array}$ & $\begin{array}{c}\text { Chi- } \\
\text { square }\end{array}$ & Df & Sig. \\
\hline $\mathbf{1}$ & $95,275(\mathrm{a})$ &, 117 &, 220 & 6,456 & 8 &, 596 \\
\hline $\mathbf{2}$ & $80,238(\mathrm{a})$ &, 202 &, 379 & 14,501 & 8 &, 070 \\
\hline
\end{tabular}

a: Estimation terminated at iteration number 6 because parameter estimates changed by less than ,001.

Results of the logistic regression model for personal accomplishment are shown in Table 14. As seen in Table 14, logistic regression analysis had two steps. In the first step, work environment predictor variable was entered into the model, and in the second step, promotion and evaluation predictor variable was added to the model. The beta coefficient (B) of work environment was 1,343 and $p$ value was 0,00 which was statistically significant at 0,05 level $(p<, 05)$. The odds ratio of work environment predictor was 3,831 and indicated that one unit increase in work environment increases 3,831 times the odds of decreasing personal accomplishment. The beta coefficient for promotion and evaluation predictor was 1,020 and $p$ value was 0,000 and significant at 0,05 level. The odds ratio of promotion and evaluation predictor was 2,774 and indicated that one unit increase in this independent variable increases 2,774 times the odds of decreasing personal accomplishment, controlling for other variables in the model. 
Table 15. Results of logistic regression for personal accomplishment

\begin{tabular}{|c|c|c|c|c|c|c|c|c|c|}
\hline & & \multirow[b]{2}{*}{ B } & \multirow[b]{2}{*}{ S.E. } & \multirow[b]{2}{*}{ Wald } & \multirow[b]{2}{*}{ Df } & \multirow[b]{2}{*}{ Sig. } & \multirow[b]{2}{*}{$\operatorname{Exp}(B)$} & \multicolumn{2}{|c|}{$\begin{array}{c}\text { 95,0\% C.I.for } \\
\text { EXP(B) }\end{array}$} \\
\hline & & & & & & & & Lower & Upper \\
\hline \multirow[t]{2}{*}{$\begin{array}{l}\text { Step } \\
1(a)\end{array}$} & $\begin{array}{l}\text { Work } \\
\text { Environment }\end{array}$ & 1,123 & ,286 & 15,435 & 1 & ,000 & 3,073 & 1,755 & 5,381 \\
\hline & Constant & 2,369 & ,336 & 49,800 & 1 & ,000 & ,094 & & \\
\hline \multirow[t]{3}{*}{$\begin{array}{l}\text { Step } \\
\text { 2(b) }\end{array}$} & $\begin{array}{l}\text { Work } \\
\text { Environment }\end{array}$ & 1,343 & ,338 & 15,799 & 1 & ,000 & 3,831 & 1,976 & 7,430 \\
\hline & $\begin{array}{l}\text { Promotion } \\
\text { and } \\
\text { Evaluation }\end{array}$ & 1,020 & ,292 & 12,224 & 1 & ,000 & 2,774 & 1,566 & 4,915 \\
\hline & Constant & 2,770 & ,413 & 44,890 & 1 & ,000 & ,063 & & \\
\hline
\end{tabular}

a: Variable(s) entered on step 1: Work Environment.

$\mathrm{b}$ : Variable(s) entered on step 2: Promotion and Evaluation.

Classification table of logistic regresson model for personal accomplishment is shown in Table 16. The correct classification percentage of low level of personal accomplishment was $98,5 \%$ and the correct classification percentage of high level of personal accomplishment was $31,6 \%$. The overall correct classification percentage of the logistic regression model was $90,0 \%$.

Table 16. Classification table of logistic regression for personal accomplishment

\begin{tabular}{|c|l|c|c|l|}
\hline \multicolumn{2}{|c|}{} & \multicolumn{2}{|l|}{ Predicted } & Percentage \\
\cline { 3 - 4 } \multicolumn{2}{|c|}{} & \multicolumn{2}{|c|}{ PA } & \\
\cline { 3 - 4 } \multicolumn{2}{|c|}{} & $\mathbf{0}$ & $\mathbf{1}$ & \\
\hline \multirow{2}{*}{$\begin{array}{c}\text { Observed } \\
\text { PA }\end{array}$} & 0 & 129 & 2 & 98,5 \\
\cline { 2 - 4 } & 1 & 13 & 6 & 31,6 \\
\hline \multicolumn{2}{|c|}{ Overall Percentage } & & & 90,0 \\
\hline
\end{tabular}

The cut value is 500

In conclusion, the logistic regression analysis indicated that there was a significant relationship between level of general burnout and work environment predictor. There was a significant relationship between level of emotional exhaustion and the predictors of work 
environment, administrative workload and academic workload. Also, there was a significant relationship between level of personal accomplishment and the predictors of work environment and promotion and evaluation. However, there was not a significant relationship between the level of depersonalization and predictor variables which was included in the model.

\section{Discussion}

Burnout levels of academicians and the factors that affect burnout levels of academicians were investigated in this study. The population for this study comprised of academicians from 78 universities in Turkey. But this study only comprised of academicians who have been working in accountant and finance sub-department in Faculties of Economics and Administrative Sciences. For the aim of the study, three questionnaires were used (sosciodemographic data form, Maslach Burnout Inventory and the scale of "work and work environment") and these questionnaires sent to 400 academic staff through electronic mail. 160 academicians responded the questionnaires. The response rate was $40 \%$. In the analysis of data, descriptive statistic (mean and standard deviation), correlation analysis, factor analysis and discriminant function analysis were used.

According to the means and standard deviations of burnout subscales, levels of burnout on academicians were lower than expected. The mean scores for emotional exhaustion, depersonalization and personal accomplishment are 10,2 (SD=6,10), 2,92 $(\mathrm{SD}=2,64)$ and $11,6(S D=3,45)$, respectively. Ozdemir et al. (1999) found out that the mean scores on emotional exhaustion were $11,93(S D=0,84)$ for academicians in Faculty of Dentistry and 12,78 (SD=0,94) for academicians in Faculty of Economic and Administrative Sciences. They found that the mean scores on depersonalization were 4,11 $(S D=0,14)$ for academicians in Faculty of Dentistry and $5,26(S D=0,69)$ for academicians in Faculty of Economic and Administrative Sciences. In their study the mean scores on personal accomplishment were also $21,86(S D=0,73)$ and $22(S D=0,78)$ for academicians in two faculties. Barut and Kalkan (2002) found that the mean scores on emotional exhaustion, depersonalization and personal accomplishment were $11,80(S D=6,17), 3,6(S D=3,44)$ and $21,7(S D=4,9)$, respectively. While the mean score on emotional exhaustion was similiar to the results of two studies, the scores on depersonalization and personal accomplishment were lower than the other studies. Particularly, the 
level of personal accomplishment was rather low. The low score on personal accomplishment indicated that academicians who have been working in accounting and finance discipline perceived low competence and success about their achievements.

The factor analysis of the 12 items which have possible effect on burnout among academicians revealed four factors: Work environment, administrative workload, academic workload and promotion and evaluation. These four factors explained $65 \%$ of the total variance. After the factor analysis, logistic regression analysis was employed to determine the predictors that affect burnout levels of academicians who have been working in accounting and finance sub-department. For this reason, four analyses were constituted for determining the predictor variables of general burnout level, emotional exhaustion level, depersonalization level and personal accomplishment level.

In the first logistic regression model which was constituted for determining the factors that affect general burnout levels of academicians, only the factor of work environment was found to be a significant predictor. The odds ratio of work environment predictor was 3,950 and indicated that one unit increase in work environment increase 3,950 times the odds of increasing general burnout level. The overall correct classification percentage of the logistic regression model was found to be $93,2 \%$. The results of the logistic regression model was constituted for determining the effect of predictor variables on emotional exhaustion level showed that the factors of work environment, administrative workload and academic workload were significant predictors for academicians. The odds ratio of work environment predictor was 5,945 and indicated that one unit increase in work environment increases 5,945 times the odds of increasing emotional exhaustion. The odds ratio of administrative workload was 2,611 and indicated that one unit increase in administrative workload increases 2,611 times the odds of increasing emotional exhaustion. The odds ratio of academic workload was 3,715 and indicated that one unit increase in academic workload predictor variable increases 3,715 times the odds of increasing emotional exhaustion. The odds ratio of promotion and evaluation was 1,889 and indicated that one unit increase in promotion and evaluation predictor variable increases 1,889 times the odds of increasing emotional exhaustion. The overall correct classification percentage of this logistic regression model was found to be $92 \%$.

In the logistic regression model which was constituted for determining the effect of predictor variables on depersonalization level of academicians, none of the factors was found to be significant 
predictor for academicians. In other words, there was not a significant relationship between depersonalization level and predictor variables.

According to the logistic regression model which was constituted for determining the effect of predictor variables on personal accomplishment, the factors of work environment and promotion and evaluation were seen to influence the personal accomplishment level of academicians. The odds ratio of work environment predictor was 3,831 and indicated that one unit increase in work environment increases 3,831 times the odds of decreasing personal accomplishment. The odds ratio of promotion and evaluation predictor was 2,774 and indicated that one unit increase in promotion and evaluation predictor increases 2,774 times the odds of decreasing personal accomplishment. The overall correct classification percentage of the logistic regression model was $90 \%$.

In general, the factors that have possible effect on burnout are divided into two groups: Personal (demographics) factors and environmental (organizational and work) factors. In this study, only possible effects of environmental factors were investigated. The effects of demographic factors on burnout are potential areas for future research. In our study, the most significant predictor of burnout was the factor of work environment, followed by the factors of administrative workload, academic workload, and promotion and evaluation.

All in all, academicians do complex work in an increasingly demanding environment. Universities are the only organizations focused on dual core functions of knowledge creation and knowledge transmission through the processes of research and teaching. But academicians have faced some problems such as heavy teaching loads, unsatisfactory reward structure, high number of students, budget concerns and insufficient research funds, low salaries and long working hours. Therefore, academicians may experience burnout at some point in their careers. Futhermore, burnout is a costly and distressing phenomenon, which damages both individuals and organizations because of the fact that burnout is associated with decreased job performance and reduced job commitment, and it predicts stress-related health problems and low job satisfaction. Hence, university administrators and academicians are aware of burnout syndrome and deal with it openly. The studies related to burnout among academicians can help and guide both university administrators and academicians.

There were some limitations in this study. First limitation of our study was the number of respondent (160 academicians). Second limitation was that the sample included only accountant and finance 
academicians, in other words, the study did not include academicians from different faculties and disciplines. Burnout levels and factors that affect burnout can be different among disciplines. Another limitation was that the sample included a wide range of academic titles; research assistant, lecturer, assistant professor, associate professor and professor. Burnout levels and factors that affect burnout can differentiate among academicians according to the academic title, because academicians in different academic career position have different work conditions, administrative and academic workload.

However, we believe that the results of this study and the other studies related to burnout among academicians can help and guide both university administrators and academicians. We recommend further follow-up studies on the burnout levels of academicians and determinants of burnout, and what is realistically required to manage or prevent burnout. 


\section{References}

Bailey, S. (2006). Burnout harms workers' physical health through many pathways. Monitor on Psychology, 37(6), Retrieved September 16th, 2006, from http://www.apa.org/monitor/jun06/burnout.html

Barut, Y., \& Kalkan, M. (2002). Ondokuz Mayıs Universitesi ogretim elemanlarının tukenmislik duzeylerinin incelenmesi. Journal of Ondokuz Mayıs University Education Faculty, 14, 66-77.

Bauer, J., Stamm A., Virnich K., et al. (2006). Correlation between burnout syndrome and psychological and psychosomatic symptoms among teachers. International Arch. Occupation Environment Health, 79, 199-204.

Bilici, M., Mete, F., Soylu C., Bekaroglu, M., \& Kavakci, O. (1998). Bir grup akademisyende depresyon ve tukenme duzeyleri. Journal of Turkish Psychiatry, 9(3), 181-189.

Briscoe, M. L. (1984). Reflections on academic burnout. ADE Bulletin, 079/Winter, 1-7, Retrieved July 12th, 2006, from http://www.mla.org/ade/bulletin/n079/079001.htm

Chalmers, A. (1998). Workload and stress in new zealand universities in 1998: A follow-up to the 1994 study. New Zealand Council for Educational Research and The Association of University Staff of New Zealand.

Doyle, C., \& Hind, P. (1998). Occupational stress, burnout and job status in female academics. Gender, Work and Organization, 5, 67 - 83.

Ergin, C. (1992). "Doktor ve hemşirelerde tükenmişlik ve Maslach tükenmişlik ölçeğinin Uyarlanması". 7. Ulusal Psikoloji Kongresi Bilimsel Çalışmaları, 143-154.

Evers, W., \& Tomic, W. (2003). Burnout among dutch reformed pastors. Journal of Psychology and Theology, 31(4), 329 - 338.

Faculty Recruitment \& Retention Committee (1999). Assessment of burnout among Southern Utah University Faculty. Faculty Recruitment \& Retention Committee Report 1998 - 1999, Retrieved July 12th, 2006, from http://www.suu.edu/academics/provost/word/frr-98-99report.doc 
Freudenberger, N.J. (1974). Staff burnout. Journal of Social Issues, 30, 159 165.

Houston, D., Meyer, L. H., \& Paewai, S. (2004). Academic staff workloads and job satisfaction: expectations and values in academe. Massey University, New Zealand.

Ing-Chung, H.,Jason, C., \& Hao-Chieh, L. (2003). The role of burnout in the relationship between perceptions of organizational politics and turnover intentions. Public Personnel Management.

Jackson, S.E., \& Maslach, C. (1982). After-Effects of job-related stress: families as victims. Journal of Occupational Behavior, 3, 63 - 77.

Jacobs, J.A.,\& Winslow, S.E.(2004). Overworked faculty: job stresses and family demands. Annals, AAPSS, 596, 104 - 129.

Jaschik, S.(2005). Stress and the female faculty member. Retrieved July 13th, 2006, from http://www.insidehighered.com/news/2005/08/23/stress

Johnson, T. (1989). A study of full-time faculty burnout at Evergreen Valley College. Retrieved June 9th, 2006, from www.eric.ed.gov/sitemap/html_0900000b80042aa9.html

Kacmaz, N. (2005). Burnout syndrome. Journal of Istanbul Faculty Medicine, 68(1), $29-32$.

Kirilmaz, A. Y., Celen, U., \& Sarp, N. (2003). Ilkogretimde calısan bir ogretmen grubunda tukenmislik durumu arastırması. Ilkogretim-Online, 2(1), 2 9.

Lackritz, J. R. (2004). Exploring burnout among university faculty: incidence, performance, and demographic issues. Teaching and Teacher Education:An International Journal of Research and Studies, 20(7), $713-729$.

Lau, P.S.Y., Yuen, M.T.,\& Chan, R. M. C. (2005). Do demographic characteristics make a difference to burnout among Hong Kong secondary school teachers? Social Indicators Research, 71, 491 516.

Lecroy, C.W., \& Rank, M.R. (1987). Factors associated with burnout in the social services an exploratory study. Journal of Social Service Research, 10(1), 23 - 39.

Marchiori, D.M., \& Henkin, A.B. (2004). Organizational commitment of a health profession faculty: dimensions, correlates and conditions. Medical Teacher, 26(4), $353-358$.

Maslach, C. (1993). Burnout: a multidimensional perspective. In W. B. Schaufeli, M. Maslach \& T. Marek (Ed.), Professional Burnout: 
Recent Developments in Theory and Research (pp.19-32). Taylor \& Francis, Washington DC.

Maslach, C.,\& Jackson, S.E. (1984). Burnout in organizational settings. Applied Social Psychology Annual, 5, 133 - 153.

Maslach, C., \& Jackson, S. E. (1985). The role of sex and family variables in burnout. Sex Roles, 12(7-8), 837-851.

Maslanka, H. (1996). Burnout, social support and AIDS volunteers. AIDS Care, 8(2), 195 - 206.

Mcdonald, T., \& Siegall, M. (1998). Burnout and expectancies about alcohol use: drinking behavior in a sample of university professors. Retrieved June 23th, 2006, from http://www.westga.edu/ bquest/2004/burnout.htm

Neidle, E.A. (1984). Faculty approaches to combating professional burnout. Journal of Dental Education, 48, 86 - 90.

Nowack, K.M., \& Hanson, A., \& Gibbons, J. (1985). Factors affecting burnout \& job performance in resident assistants. Journal of College Student Personnel, 26, 137 - 142.

Ozdemir, K., Coskun, A., Ozdemir, D., \& Cinar, Z. (1999). Dishekimligi fakultesi ogretim elemanlarında mesleki tukenmislik olceginin degerlendirilmesi. Journal of Cumhuriyet University Dentistry Faculty, 2(2), 98 - 104.

Pagel, I., \& Wittmann M. E. (1986). Relationship of burnout to personal and jobrelated variables in acute-care pediatric settings. Issues Compr. Pediatr Nurse, 9(2), 131 - 143.

Piko, B. F. (2006). Burnout, role conflict, job satisfaction and psychosocial health among hungarian health care staff: a questionnaire survey. International Journal of Nursing Studies, 4, 311 - 318.

Poulin, J., \& Walter, C. (1993). Social worker burnout: a longitudinal study. Social Work Research and Abstracts, 29(4), 5 - 11.

Rocca, A.D., \& Kostanski, M. (2001). Burnout and job satisfaction amongst victorian secondary school teachers: a comparative look at contract and permanent employment. ATEA Conference, 24-26 September, Melbourne.

Sari, H. (2004). An analysis of burnout and job satisfaction among turkish special school headteachers and teachers, and the factors effecting their burnout and job satisfaction. Educational Studies, 30(3).

Schaufeli, W., \& Janczur, B. (1994). Burnout among nurses: a polish-dutch comparison. Journal of Cross-Cultural Psycholog, 25, 95 - 113. 
Schwab, R., \& Jackson, S. E., \& Schuler, R. S. (1986). Educator burnout: sources and consequences. Educational Research Quarterly, 10(3), $14-30$.

Seiler, R.E., \& Pearson, D.A. (1984). Stress among accounting educators in the United States. Research in Higher Education, 21(3), 301 - 316.

Siebert, D.C. (2006). Personal and occupational factors in burnout among practicing social workers implications for researchers, practitioners, and managers. Journal of Social Service Research, 32(2), 25 - 44.

Siegall, M., \& Mcdonald, T. (2004). Person-organization value congruence, burnout and diversion of resources. Personnel Review, 33(3), 291 301.

Singh, S.N., Mishra, S., \& Kim, D. (1998). Research-related burnout among faculty in higher education. Psychological Reports, 83(2), 463 - 73.

Sucuoglu, B., \& Kuloglu, N. (1996). Ozurlu cocuklarla calısan ogretmenlerde tukenmisligin degerlendirilmesi. Journal of Turkish Psychology, 10(36), $44-60$.

Sunter, A. T., Canbaz, S., Dabak, S., Oz, H., \& Peksen, Y. (2006). Pratisyen hekimlerde tukenmislik, ise baglı gerginlik ve is doyumu duzeyleri. Journal of General Medicine, 16(1), 9 - 14.

Talbot, L. A. (2000). Burnout And Humor Usage Among Community College Nursing Faculty Members. Community College Journal of Research and Practice, 24, $359-373$.

Taycan, O., Kutlu, L., Cimen, S., Aydin, N. (2006). Bir universite hastanesinde calısan hemsirelerde depresyon ve tukenmislik düzeyinin sosyodemografik ozelliklerle iliskisi. Anatolian Journal of Psychiatry, 7, $100-108$.

Todd-Mancillas, W. R., \& Johnson, P. (1987). Academic burnout: one perspective. Retrieved July 13th, 2006, from www.eric.ed.gov/sitemap/html_0900000b80112cc8.html

Toppinen-Tanner, S., Ojajarvi, A., Vaananen, A., Kalimo, R., \& Jappinen, P. (2005). Burnout as a predictor of medically certified sick-leave absences and their diagnosed causes. Behavioral Medicine, Spring.

Tytherleigh, M. Y., Webb, C., Cooper, C. L., \& Ricketts, C. (2005). Occupational stress in UK higher education institutions: A comparative study of all staff categories. Higher Education Research and Development, 24(1), $41-61$.

University Of Plymouth, Institute Of Health Studies (2003). Occupational stress in higher education institutions: Phase I results for all HElsl. Retrieved May 26th, 2006, from http://www.ihs. plymouth.ac.uk/ stresshe/worddoc/51077.doc 
Uskun, E., Ozturk, M., Kisioglu, A. N., Kirbiyik, S. (2005). Burnout and job satisfaction amongst staff in Turkish community health services. Primary Care and Community Psychiatry, 10(2), 63 - 69.

Zellars, K. L., Perrewe, P. L., \& Hochwarter, W. A. (2000). Burnout in health care: the role of the five factors of personality. Journal of Applied Social Psychology, 30(8), 1570. 